\title{
CONSTITUTIONAL QUESTIONS CONCERNING COGNOVIT NOTES
}

\author{
WARREN A. THORNHILL*
}

In some states, cognovit notes, or warrants of attorney, 1 are widely used to strengthen the security of creditors, and legislatures have shown their approval by enacting statutes providing for the enforcement of the device in the courts. ${ }^{2}$ Serious problems have arisen because other states have found the device so offensive to their policies that they have enacted statutes prohibiting its use. ${ }^{3}$

Suppose that $A$, a citizen and resident of Texas, in return for a loan, gives $B$, also a citizen and resident of Texas, a promissory note. Let us further suppose that $B$ refuses to lend the money to $A$ unless the latter includes in the note a provision authorizing any attorney at law to confess judgment against him. $B$, realizing that the courts of Texas will not give effect to the cognovit provision, goes to Illinois (although there are, no doubt, states nearer than Illinois which would enforce the provision); there, an Illinois court renders judgment for $B$ and against $A$ without giving notice to $A$ of the proceeding. $B$ then returns to Texas and seeks to obtain enforcement of the Illinois judgment by a Texas court. On its face, the hypothetical transaction just stated would seem to be of no validity; but, would not the

* 2nd Year Law Student, Duke University; V.P.I. 1946-1949.

1 Under the old common law, the warrant of attorney was distinguished from the cognovit note in that the former was not a part of the promissory note but was a separate document; also, the warrant of attorney was under seal, while a cognovit note was not. Irose v. Balla, 181 Ind. 491, 104 N.E. 851 (1914). The tendency today is to use the terms interchangeably.

2 For example, see InL. Stat. ANr., Sec. 104.050 (1949 Supp.).

${ }^{3}$ See TEx. Crv. STat., Art. 2224 (1950). See also, N. C. G. S. \$25-11 (1943), which would seem to indicate that North Carolina disallows cognovits; but Monarch Refrigerating Co. v. Farmers' Peanut Co., 74 F. 2d 790 (4th Cir. 1935), holds that the Statutory provision is mereiy procedural, and does not prohibit use of cognovit notes. The cognovit device has the effect of cutting off the defenses of the maker; the extent to which those defenses are cut off is not within the purview of this article. 
full faith and credit clause of the Constitution require that Texas render judgment for $B$ on the Illinois judgment?

Or suppose a suit is brought in Alabama on a judgment rendered in Illinois, the judgment being rendered on a cognovit note which is invalid by Alabama statute. In such a case, where the notes were dated and made payable in Illinois, though actually executed in Alabama, the court said :

"It [the cognovit provision] was void under the statute law of this state, and being void where entered into, it was everywhere, and of consequence could not be relied upon to give jurisdiction to the Illinois court."

And again:

"The warrant of attorney, upon which the Illinois court acted, was the only foundation for any pretence that the defendant was a party to the cause or had a day in court, and if such power was void the jurisdiction was destroyed."

But in Barber Co. v. Hughes, ${ }^{5}$ the Indiana court took a lifferent view. There the plaintiff was the assignee of a cognovit note which had been signed in Indiana by a resident of that state for a debt owed the plaintiff's assignor, a corporation doing business in the state of Illinois. The Indiana statute declares such notes void and provides that no court of that state shall aid or enforce the collection of any judgment which may be rendered upon any judgment obtained in any other state and founded on such a cognovit. But, because of the Illinois contacts, the court held that the law of Illinois applied, and of the cognovit it said:

"It constituted a voluntary waiver of the necessity for a personal service and became effective when acted upon. Consent being thus given to the Illinois court, in a manner recognized as valid under its laws, the judgment rendered pursuant thereto was entitled to full faith and credit everywhere and was properly recognized and enforced in Indiana."

- Monarch Refrigerating Co. V. Faulk, 228 Ala. 554, 155 S. 74 (1934).

- 223 Ind. 570, 63 N. E. 2d 417 (1945). 
The two cases just mentioned demonstrate that the outcome of the hypothetical case could be doubtful, although its facts are, perhaps, indicative of what a just result would be.

In a recent case, Turner v. Alton Banking \& Trust Company, ${ }^{6}$ petition for writ of certiorari to the Court of Appeals for the Eighth Circuit was denied by the Supreme Court. The Alton Banking \& Trust Company, executor of the deceased creditor, had obtained an Illinois court judgment on a note which provided:

"If this note is not paid at maturity, we ... do hereby ... empower any attorney of any Court of Record to appear for us . . . at any time hereafter and confess a judgment without process against us . . . in favor of the legal holder thereof ...."

The defendant was living in Missouri at the time this judgment was rendered against him although he had been a resident of Illinois at the time the note was issued. The plaintiff sought enforcement of this judgment in the United States District Court for the Eastern District of Missouri, jurisdiction being based on diversity of citizenship; that court entered judgment upon a verdict for the plaintiff, and the Court of Appeals affirmed.

"Full Faith and Credit shall be given in each State to the public Acts, Records, and judicial proceedings of every other State." Is there anything about a judgment rendered on a cognovit note, such as appears in the Turner case, which excludes it from the effect of the provision just quoted? The Court of Appeals thought not and cited Crim v. $\mathrm{Crim}^{8}$ to support this view. That latter case seems to express the position of a majority of the decisions; and although the main case is the only federal case which has cited it, a number of state courts have considered it an authoritative opinion.9

- 340 U.S. 833 and 885 (1950).

U.S. Const., Art. IV, Sec. 1.

162 Mo. 554, 63 S.W. 489 (1901).

- See generally, Note, 26 VA. L. R. 952 (1940). 
But it is the dissenting opinion of Justice Valliant in Crim v. Crim, supra, which is of interest for the purpose of this discussion. This dissent presents a view which surprisingly few of the state courts most opposed to the use of cognovits have utilized. The facts of the case were that the defendant, a resident of Missouri, had, while in the state of Ohio, executed a cognovit note to the plaintiff, a resident of Ohio; under the authorization given, an attorney entered confession of judgment in an Ohio court against the defendant, and the plaintiff brought action on the judgment in the Missouri court. Justice Valliant said that the question was one of jurisdiction; and of the confession of judgment entered by the attorney, he said:

"Suppose there had been no such authorization in the note, and an attorney at law, without any authority from defendant whatever, had entered his appearance and suffered judgment to go ... [T] he decisions above cited ${ }^{10}$ are authority for saying that, if that judgment should be sued on here, the defendant may avoid it by a plea showing that the court had no jurisdiction of his person. Now, the supposed case differs from the case at bar only in this: that in that case there was no semblance of authority to the pragmatical attorney, while here there is claimed to be authority. But, if what is here claimed to be authority is no authority, then there is no difference between the cases."

A few remarks are necessary to clarify the dissenter's position. A judgment rendered in one state, if valid in that state, must be honored by another state; but, if the court which rendered the judgment did not have jurisdiction of the subject and the person, then the judgment is void under the due process clause of the Fourteenth Amendment and does not come within the full faith and credit clause. The rule was stated in clear terms in Thompson $v$. Whitman, ${ }^{11}$ where Mr. Justice Bradley, speaking for the court,

${ }^{10}$ D'Arcy v. Ketchum, 11 How. 165, 13 L. Ed. 648 (1850); Pennojer จ. Neff, 95 U.S. 714 (1878).

य 18 Wall. 457, 21 L. Ed. 897 (1874). 
said that neither the constitutional provision that full faith and credit should be given in each state to the judicial proceedings of every other state, nor the act of Congress passed in pursuance thereof, prevented an inquiry into the jurisdiction of the court which had rendered a judgment offered in evidence. ${ }^{12}$

Although Justices Black and Douglas were of the opinion that it should have been granted, certiorari was denied by the Supreme Court in Turner v. Alton Banking \& Trust Company. A majority of the United States Supreme Court thus denied review in a case where the due process question was disposed of by the single statement:

"Due process does not require notice where rights are established in conformity with state law."

As authority for this statement, the Court of Appeals ${ }^{13}$ cited Erie R.R. v. Tompkins, ${ }^{14}$ and Griffin v. Griffin. ${ }^{15}$ It is the Griffin case which must be examined in order to find support for the statement. In that case the action was for the recovery of a judgment for arrears for alimony. In 1935 the plaintiff therein had recovered in the New York Supreme Court a judgment against the petitioner for $\$ 18$,493.64 in accrued installments of alimony and interest; petitioner did receive notice and hearing in connection with this judgment. Then in 1938, the New York Supreme Court rendered a judgment against the petitioner ex parte, without notice to him, for the sum of $\$ 25,382.75$, which sum included the amount of the 1935 judgment plus additional arrears and interest. Petitioner contended that the

12 This rule is subject to an exception where the court rendering the judgment has passed upon the question of its own jurisdiction upon a contested hearing of that question. Of course, this exception would be inapplicable in the cognovit note cases. See Davis v. Davls, 305 U.S. 32 (1938).

13 181 F. 2d 899 (8th Cir. 1950).

14 304 U.S. 64 (1938). It seems clear that this case was cited for its rule that a federal court in enforcing State-created rights is required to follow the State law. It seems unnecessary to stress that this rule is operative only if the State law is constitutional.

15 327 U.S. 220 (1945). 
judgment was void for want of due process, and the case ultimately arrived in the United States Supreme Court. It was when that court was speaking of the $\$ 18,493.64$ that it said:

"Due process does not require that notice be given before confirmation of rights theretofore established in a proceeding of which adequate notice was given."

To spell this out, the petitioner contended that judgment for the full amount of $\$ 25,382.75$, which had been rendered ex parte, was void; but the court answered that this was not true, at least, to the extent of the $\$ 18,493.64$.

But in Turner v. Alton Banking \& Trust Company, the instant case, nothing that could be called "adequate notice" was given. The rights were established only in conformity with the Mlinois statute which reads in part:

"Any person for a debt bona fide due may confess judgment by himself or attorney duly authorized either in term or vacation, without process." 16

The Court of Appeals seems to have indulged in some circular reasoning here: the appellant was complaining that the procedure by which his property was taken was without due process of law because of the invalidity of the statute authorizing it; the court then answered the due process objection, without considering the validity or invalidity of the statute, by saying that the proceeding was effectual because the property was taken in conformity with the statute.

The Supreme Court went a step further in the Griffin case, supr'a, and while conceding that the original divorce decree gave the petitioner notice that additional proceedings might occur because of his obligation to pay installments accruing under the decree, said:

"We find in this no ground for saying that due process does not require notice of the time and place of such further proceedings, inasmuch as they undertook substantially to affect his rights in ways in which the 1926 decree did not."

${ }^{16}$ IxL. Stat. ANN., Sec. 104.050 (1949 Supp.). 
In the main case, if it be said that the appellant had notice, at the time when he authorized any attorney to appear for him and confess judgment against him without process, that the act authorized might at some time be performed, does it follow that in waiving his right to be served with process, he also effectually waived the right to "further notice of the time and place" of the proceedings? Admittedly, if the authorization was to have the effect accorded it by the court, then an affirmative answer is required to this question. But it is submitted that the cases cited by the court do not require such an answer, although this is not to say that authority supporting the court's position was unavailable.

Beginning with the proposition, for which justification will subsequently be suggested, that a process which is unreasonable and unfair is prima facie not due process of law; let us tentatively assume, in accordance with the views of many legislatures and courts, that the cognovit process is unreasonable and unfair. What arguments have been accepted by the courts as sufficient to overcome this prima facie case and support the constitutionality of the cognovit process?

To begin with, federal decisions on the subject are very scarce. The device has been "recognized and ruled upon by the United States Supreme Court."17 But this last statement shows a very careful choice of words which aptly describes the lack of Supreme Court decisions absolutely passing upon the constitutionality of cognovits. The next question is, how would the Supreme Court justify the cognovit constitutionally if it were squarely faced with the question? The case of French $v$. Willer ${ }^{18}$ suggests an answer to this question by its statement that the

"practice of entering judgment in debt on warrants of attorney is very old; so old that the date of its origin is unknown." 19

${ }^{17}$ Bower v. Casanave, 44 F. Supp. 501, 507 (S.D. N.Y 1941).

18126 Ill. 711, 18 N.E. 811 (1888).

19 Teel . Yost, 128 N.Y. 387, 28 N.E. 353 (1891), gives an excellent history of warrants of attorney in New York and gives evidence of their use in that state as early as 1774. 
The suggestion of that statement is the possible application of the "settled usages and modes" doctrine by which a proceeding otherwise found wanting in due process is justified. ${ }^{20}$ An example of how this doctrine can be applied to a proceeding which might otherwise be treated as inconsistent with due process is Ownby v. Morgan. ${ }^{21}$ There a Delaware statute provided that, before a defendant to a foreign attachment proceeding could contest the action, he would be required to put up as security property equal in value to that held under the attachment. The defendant in that action possessed no property other than that attached and thus was precluded from contesting the attachment. The Supreme Court said:

"A procedure customarily employed, long before the Revolution, in the commercial metropolis of England, and generally adopted by the states as suited to their circumstances and needs, cannot be deemed inconsistent with due process of law."

It might be argued that the above statement could be used to justify the constitutionality of cognovit notes. But the argument seems too broad to be convincing. The fact that a procedure was employed in England prior to the Revolution would seem to have little relation to its constitutionality today; indeed, the Revolution has often been thought of as an event calculated to end certain legal procedures which were considered to be oppressive. It is only when a traditional procedure has been "generally adopted by the states as suited to their circumstances and needs" that a strong case in favor of its constitutionality is made out.

It is doubtful whether the cognovit note can meet this latter test; for, in addition to the fact mentioned earlier that the device is outlawed in many states, the courts in general have shown little liking for cognovits and have invalidated them, if not on due process grounds, ${ }^{22}$ by strict

־ Murray v. Hoboken Land, etc. Co., 18 How. 272 (1855).

2 256 U.S. 94 (1921).

22 For a case implying that cognovits are lacking in due process, see Bernard Gloeckler Co. v. Baker Co., Tex. Civ. App., 52 S.W. $2 d 912$ (1932). 
construction ${ }^{23}$ where possible, and by refusal to extend their use beyond the field of contracts. ${ }^{24}$ These facts tend to suggest that the courts recognize that there is something inherently unfair in the device.

Having seen that the courts have given few reasons to support their upholding of the cognovit note process, and that there is some doubt that it could be supported even on the ground of traditional acquiescence, it seems clear that what the courts are really relying on is jurisdiction conferred by consent, ${ }^{25}$ with the normal due process requirement of notice being deemed dispensed with by waiver. This reliance on consent could not be questioned if the nineteenth-century standards of decision yet prevailed. But in recent years the Supreme Court has significantly departed from the rigid scheme of jurisdictional bases previously recognized, mainly because the concept of "consent" had been strained beyond the breaking point. Before speculating on the possibility and practicability of applying the modern approach to the cognovit note situation, an examination of some of the cases illustrating the recent departure might be illuminating.

Suppose a motorist of one state runs over someone while traveling through a second state. It seems clear that it would be just to require the motorist to defend himself in the courts of the state wherein the accident occurred; however, it is also clear that the fulfillment of the consent requirement would in rare cases be an actuality. An excel-

${ }^{23}$ One of the many cases expressing this doctrine is Nardi $\nabla$. Poinsatte, 46 F. $2 \mathrm{~d} 347$ (1931). It is true that in that case there was some evidence of fraud. But aside from that, the court held that where one authorizes any attorney of any court of record to appear and confess judgment against him, he is not bound by the acts of one who was not shown in the proceedings to have been an attorney of a court of record, but was only shown to have been an attorney.

24 See French V. Willer, 126 Ill. 711, 18 N.E. 811 (1888), where the court says that the practice of entering judgment by confession upon warrant of attorney, without process, is not appilicable in actions of tort.

${ }_{25}$ For the usual bases of jurisdiction, see Scott Jurisdiction Over Nonresidents Doing Business Within a State, 32 HARv. L. R. 871 (1919). 
lent case for showing two of the steps taken by the courts in getting around this requirement is Hess $v$. Pawloski:26

"[I]n advance of the operation of a motor vehicle on its highway by a nonresident, the state may require him to appoint one of its officials as his agent on whom process may be served in proceedings growing out of its use. Kane v. New Jersey, 242 U.S. 160. That case recognizes power of the state to exclude a nonresident until the formal appointment is made. And, having the power so to exclude, the state may declare that the use of the highway is the equivalent of the appointment of the registrar as agent on whom process may be served."

It can be seen that the courts in effect have abandoned "consent" as a requirement of jurisdiction in favor of a more practical and realistic approach which treats the motorist as within the jurisdiction of the state in question when the circumstances seem to justify his treatment as such.

The broadening of jurisdiction to include foreign corporations has also taken place by gradual steps. The first step was the formulation of the theory that a state could exclude a foreign corporation entirely since corporations were not deemed "persons" for the purpose of the privileges and immunities clause. Then it was decided that if a corporation was found to be present within a state, it was said to have agreed to certain conditions of entry, among these, consent to jurisdiction. But even after these steps in the direction of a practical solution to the jurisdiction problem, the courts seemed to feel bound by strict definitions of "present" and "presence." As pointed out by Justice Learned Hand in Hutchinson v. Chase \& Gilbert, ${ }^{27}$ this did not lead to a uniform line of decisions. The opinion just mentioned liberalized this strict adherence to definition by giving a "continuous dealings" test which would insure more practical results than the former formalistic

s9 274 U.S. 352 (1927).

${ }^{27} 45$ F. 2d 139 (2d Cir. 1930). 
approach. The view today is even more liberal as is shown by International Shoe Co. v. Washington: $:^{28}$

"[D] ue process requires only that in order to subject a defendant to a judgment in personam, if he be not present within the territory of the forum, he have certain minimum contacts with it such that the maintenance of the suit does not offend traditional notions of fair play and substantial justice."

But the difference in the two approaches can best be seen in application to specific facts. Suppose that the state of Virginia, under its "Blue Sky Law," ordered a Nebraska insurance association to cease operations until, among other things, it consented to suit by service of process on the Secretary of the Commonwealth. The Nebraska association had for several years been conducting business by mail with some seven or eight hundred customers in Virginia. Now, the defendants challenge the jurisdiction of Virginia, and move to quash the service of summons, which was sent by registered mail. Under the old and strict approach to jurisdiction, it would be difficult to come out with the result that the defendants were within the jurisdiction of Virginia; to do so it would have been necessary to find that they were "present" in Virginia and they had thus "consented" to jurisdiction. But, looking at the amount of business conducted by the association in Virginia, it would seem that it should be treated as within that state's jurisdiction. Under the facts given, the Supreme Court did reach such a result as that last suggested in Travelers Health Assn. v. Virginia: ${ }^{29}$

"But where business activities reach out beyond one state and create continuing relations and obligations with citizens of another state, courts need not resort to a fictional 'consent' in order to sustain the jurisdiction of regulatory agencies in the latter state."

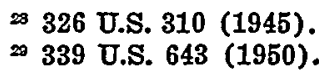


And of the old approach, the court said :

'Metaphysical concepts of 'implied consent' and 'presence' in a state should not be solidified into a constitutional barrier against Virginia's simple, direct and fair plan for service of process on the Secretary of the Commonwealth."

In still another related area of jurisdiction, form and formula appear to be breaking down in favor of a more realistic approach; that is in connection with the nonresident individual doing business within a state. The process of reasoning applied to foreign corporations was, in this area, found to be inapplicable because the individual was protected by the privileges and immunities provision; thus he could not be excluded from the state entirely, and so there could be no conditions on his entering the state. But the same broadening of jurisdiction is taking place. In Doherty \& Co. v. Goodman, ${ }^{30}$ an Iowa statute was involved which provided that service could be made on an agent of an individual or corporation doing business in the state in all actions growing out of or connected with the business. The defendant there was an individual who resided in New York and who conducted a business of selling securities, one of the areas of his sales being Iowa where an agent conducted the business. The defendant challenged the jurisdiction of the Iowa court which served process on his Iowa agent in an action arising out of a sales contract. The Supreme Court affirmed a judgment for the plaintiff, but indicated its intention to limit its holding to that set of facts; however, it seems doubtful that this limitation will long remain.

Fairness and justice seems to have been the chief guiding lines for the courts in broadening the jurisdiction of state courts so as to include foreign corporations, nonresident motorists and, to a limited degree, nonresident individuals. This has taken place following a recognition by the courts of the fact that adherence to the conceptualistic bases of jurisdiction excluded from the jurisdiction of par-

so 294 U.S. 623 (1935). 
ticular courts certain actions which should not have been so excluded. The most logical step next to be taken, would seem to be the narrowing of the jurisdiction of state courts over certain of the cognovit note cases. If at first glance it appears an illogical step to move from a disregard of implied consent in broadening jurisdiction to a disregard of prior expressed consent in narrowing jurisdiction, it is submitted that the logical nature of the move is more apparent upon the realization that in each instance the goal is a more practical approach to jurisdiction. It is true that the desirability of disregarding "implied consent" as a criterion for obtaining a legal conclusion is ordinarily greater than it is for disregarding "express consent"; but it would seem that the economic duress behind the express consent in the cognovit situation should place it on a level with "implied consent" as a fiction.

Probably the outcome of cases such as the principal case of Turner v. Alton Banking \& Trust Company would be no different under this approach. But, in cases where the whole cognovit transaction takes place in a state expressly disallowing the transaction, and where the state court rendering the questioned judgment has no grounds for exercising its jurisdiction other than the fact that the holder of the note has sought a favorable court, there would, under this approach, be a different result. In addition to situations like that just mentioned, a number of cases falling somewhere between that situation and the main case could well be found to have offended "traditional notions of fair play and substantial justice."

Because of the conflicting nature of the state statutes concerning cognovit notes, the problems occurring from the use of the device seem to be on the incline. In view of this fact, it does not seem unlikely that the Supreme Court will at some time be faced with a strong case for showing the unfairness of the transaction; when and if that happens, this writer suggests that the traditional bases for the exercise of jurisdiction may be contracted. 